\title{
Active Monomer RTR-I Derived from the Root of Rhodomyrtus tomentosa Induces Apoptosis in Gastric Carcinoma Cells by Inducing ER Stress and Inhibiting the STAT3 Signaling Pathway
}

This article was published in the following Dove Press journal:

Cancer Management and Research

\begin{abstract}
Xiangqiang Zhang ${ }^{1} * *$
Jinxia Cheng $\mathbb{D}^{1, *}$

Peiyan $\mathrm{He}^{2}$

Jinyan $\mathrm{Zhu}^{3}$

Zhixian Chen ${ }^{2}$

Shenyu Miao ${ }^{4}$

Guocai Wang ${ }^{5}$

Jianwei Jiang (iD ${ }^{2}$

Yuechun Wang'

'Department of Physiology, Basic Medical College, Jinan University, Guangzhou 510630, People's Republic of China; ${ }^{2}$ Department of Biochemistry, Basic Medical College, Jinan University, Guangzhou 510630, People's Republic of China; ${ }^{3}$ Department of Immunology, Basic Medical College, Jinan University, Guangzhou 510630, People's Republic of China; ${ }^{4}$ School of Life Sciences, Guangzhou University, Guangzhou, People's Republic of China; ${ }^{5}$ Institute of Traditional Chinese Medicine and Natural Products, College of Pharmacy, Jinan University, Guangzhou 510630, People's Republic of China

*These authors contributed equally to this work
\end{abstract}

Correspondence: Jianwei Jiang Department of Biochemistry, Basic Medical College, Jinan University,

Guangzhou 510630, People's Republic of China

Email jjw703@jnu.edu.cn

Yuechun Wang

Department of Physiology, Basic Medical College, Jinan University, Guangzhou 5 10630, People's Republic of China

Email 8936892I4@qq.com
Purpose: Rhodomyrtus tomentosa, a flowering plant from the Myrtaceae family, is considered an antitumour substance with versatile biological and pharmacological activities. RTR-1 is an active monomer purified from the root of Rhodomyrtus tomentosa. However, the detail of mechanism involving in RTR-1 anti-cancer activity remains to be elucidated, and the effect on gastric cancer cells is unknown.

Methods: Cell proliferation was determined by MTT and clone formation assay. The effect of RTR-1 on cell cycle distribution and apoptosis was analysed utilizing flow cytometry, respectively. Moreover, Western blotting was used to detect the expression of cell cycle- and apoptosis-related protein.

Results: Based on MTT and clone formation assay, we noticed that RTR-1 inhibited the proliferation of gastric carcinoma (BGC823 and SGC7901) cells in a dose- and timedependent manner. Furthermore, the results of flow cytometry and Western blotting showed that RTR-1 induced cell cycle arrest in the G2/M phase through the ATM-Chk2-p53-p21 signaling pathway and induced cell apoptosis by inhibiting the signal transducers and activators of transcription 3 (STAT3) pathway and activating the endoplasmic reticulum stress (ER stress) pathway.

Conclusion: Taken together, these results demonstrate that RTR-1 induces cell cycle arrest and promotes apoptosis in gastric carcinoma, indicating its potential application for gastric cancer therapy.

Keywords: RTR-1, gastric carcinoma cells, cell cycle, apoptosis, ER stress, STAT3

\section{Introduction}

Gastric cancer (GC) remains the second leading cause of cancer deaths worldwide. Each year, approximately 990,000 people are diagnosed with GC worldwide, and approximately 738,000 people die from this disease, ${ }^{1}$ making GC the 4 th most common cancer by incidence and the 2 nd most common cause of cancer death. ${ }^{2}$ Although the global incidence of gastric cancer has decreased in recent years, in China, mortality from $\mathrm{GC}$ is the highest among all tumours and represents $25 \%$ of the mortality caused by gastric cancer worldwide. ${ }^{3}$ Although many gratifying achievements are attributable to the use of multidisciplinary approaches for treatment, such as surgery, interventional treatment, biological treatment and so on, drug treatment is still the main treatment for most gastric cancer patients, especially patients with advanced disease. 
Despite increased understanding of the biological processes in cancer development, there is still a great need for novel and effective pharmacological strategies for the intervention of many types of cancers. Pharmacological agents that induce apoptosis might be effective against many cancers by inducing death in cancer cells. ${ }^{4}$ In fact, a great number of clinically active drugs that are used in cancer therapy are either natural products or are based on natural products. Established plant-derived therapeutics include vinblastine, vincristine, etoposide, teniposide, paclitaxel, docetaxel, and camptothecin. In addition, numerous plant extracts, including tea polyphenol, resveratrol, ginger extract and soy isoflavones, have been found to demonstrate potential antitumour effects, providing a new direction for the study of new anticancer drugs. ${ }^{5}$

Rhodomyrtus tomentosa is a flowering plant belonging to the Myrtaceae family. It is primarily native to Southeast Asian countries, especially Vietnam, China, Japan, Thailand, the Philippines, and Malaysia. It has been used in traditional medicine for the treatment of many diseases, including dysentery and urinary tract infections, and as an antiseptic wash for wounds. In addition, myrtle extracts have been reported to be as efficient as antibacterial properties $^{6}$ and potent natural antioxidants. ${ }^{7}$ Furthermore, a study showed that Rhodomyrtus tomentosa has an immunomodulatory effect on innate immune responses ${ }^{8}$ and can work as a potential anti-proliferative and apoptosisinducing agent in $\mathrm{HaCaT}$ keratinocytes. ${ }^{9}$ In the course of searching for natural anticancer compounds, we evaluated nine compounds for their anti-proliferative action in BGC823, SGC7901, SK-Mel-110 and SMMC7721 cells. The MTT results showed that RTR-1 had the most potent cytotoxicity among four cancer cells. Therefore, we chose RTR-1 as the research subject to explore the molecular mechanism of inhibiting the growth of gastric cancer cells.

In this study, we found that RTR-1 blocks cell cycle progression at the G2/M phase in a ROS-dependent manner. Moreover, RTR-1 also induces caspase-regulated apoptotic cell death by activating ER stress and inhibiting the STAT3 signaling pathway. Our study suggests that RTR-1 may be a new source of anticancer compounds.

\section{Materials and Methods}

\section{General Experimental Procedures}

Optical rotations were recorded on a JASCO P-1030 automatic digital polarimeter, and UV spectra were recorded with a JASCO V-550 UV/VIS spectrophotometer. IR spectra were determined using a JASCO FT/IR-480 plus FT-IR spectrometer. HRESIMS data were determined by an Agilent 6210 ESI/TOF mass spectrometer. NMR spectra were obtained by a Bruker AV-400 spectrometer with TMS as an internal standard. Preparative HPLC was performed using a Varian chromatograph equipped with a C18 reversed-phase column (Cosmosil, $5 \mu \mathrm{m}, 10 \mathrm{~mm} \times$ $250 \mathrm{~mm}$ ). Analytical HPLC was performed using a Waters chromatograph equipped with a $\mathrm{C} 18$ reversed phase column (Cosmosil, $5 \mu \mathrm{m}, 4.6 \mathrm{~mm} \times 250 \mathrm{~mm}$ ). Silica gel (200-300 mesh; Qingdao Marine Chemical, Inc.), ODS silica gel (50 $\mu \mathrm{m} ;$ YMC), and Sephadex LH-20 (Pharmacia) were used for column chromatography experiments. Silica gel GF254 plates (Yantai Chemical Industry Research Institute, Yantai, China) were used for thin-layer chromatography (TLC).

\section{Materials}

The dried roots of $R$. tomentosa were purchased in Guangzhou, Guangdong Province, China, in March 2013. The plant was authenticated by Zhenqiu Mai, the senior engineer of a medicinal materials company in Guangdong Province. A voucher specimen (20130330) was deposited in the Institute of Traditional Chinese Medicine and Natural Products of Jinan University.

\section{Extraction and Isolation}

The dried roots of $R$. tomentosa $(25.0 \mathrm{~kg})$ were pulverized and extracted with $95 \%$ aqueous ethanol $(100 \mathrm{~L})$ at $50^{\circ} \mathrm{C}$ three times. The ethanol extract was concentrated in vacuo to obtain a crude extract $(1.6 \mathrm{~kg})$. The crude extract was suspended in water and partitioned with petroleum ether $(2.5 \mathrm{~g})$ and ethyl acetate $(651.3 \mathrm{~g})$. The ethyl acetate extract was subjected to silica gel column chromatography using a cyclohexane/ethyl acetate system (100:0 to 0:100, v:v) in eight fractions (Fr. A-H). Moreover, Fr. D was eluted by chromatography with a chloroform/methanol gradient on a silica gel column, which yielded compound RTR-9 (240.5 mg) and RTR-10 (3.3 mg). Additionally, Fr. $\mathrm{G}$ was further separated by silica gel column chromatography with chloroform/methanol (100:0 to 0:100, v:v) and was purified by a Sephadex LH-20 $\left(\mathrm{CHCl}_{3} / \mathrm{MeOH}\right.$, 50:50, v/v) column and preparative HPLC with $\mathrm{MeOH}-\mathrm{H}_{2}$ O, which yielded compound RTR-1 (124.5 mg), RTR-2 (30.6 mg), RTR-3 (42.6 mg), RTR-4 (26.7 g), RTR-5 (72.8 mg), RTR-6 (81.4 mg), RTR-7 (8.4 mg), RTR-8 (24.1 mg), RTR-11 (3.4 mg), RTR-14 (0.9 g), RTR-15 (6.1 mg), RTR-16 (2.1 mg), RTR-17 (1.4 mg), RTR-18 
(542.5 mg), and RTR-19 (9.0 mg). Moreover, the chemical structure of RTR-1, RTR-2, RTR-3, RTR-4, RTR5, RTR-6, RTR-8, RTR-9, RTR-17 are showed in Figure 1.

The following data were obtained on RTR-1: white powder; $[\alpha] 25 \mathrm{D}+10.7$ (c $0.64, \mathrm{CH}_{3} \mathrm{OH}$ ), HRESIMS m/z $657.3762[\mathrm{M}+\mathrm{Na}]+$ (calcd for $\mathrm{C}_{39} \mathrm{H}_{54} \mathrm{O}_{7} \mathrm{Na}, 657.3762$ ); $\mathrm{UV}\left(\mathrm{CH}_{3} \mathrm{OH}\right) \lambda \max 227,313 \mathrm{~nm}$; IR $(\mathrm{KBr})$ vmax 3312, 2946, 1698, 1631, 1604, 1515, 1455, 1270, 1170, 1048, and $831 \mathrm{~cm}-1$; $1 \mathrm{H} \mathrm{NMR} \mathrm{(400} \mathrm{MHz,} \mathrm{Pyr-d5)} \delta_{\mathrm{H}}: 7.93(1 \mathrm{H}$, d, J = 15.6 Hz, H-3') $7.51\left(2 \mathrm{H}, \mathrm{d}, \mathrm{J}=8.4 \mathrm{~Hz}, \mathrm{H}-5^{\prime}, 9^{\prime}\right)$, $7.13\left(2 \mathrm{H}, \mathrm{d}, \mathrm{J}=8.4 \mathrm{~Hz}, \mathrm{H}-6^{\prime}, 8^{\prime}\right), 6.53(1 \mathrm{H}, \mathrm{d}, \mathrm{J}=15.6 \mathrm{~Hz}$, H-2'), $5.79(1 \mathrm{H}, \mathrm{ddd}, \mathrm{J}=12.4,10.0,4.4 \mathrm{~Hz}, \mathrm{H}-2), 5.50$ $(1 \mathrm{H}, \mathrm{br} \mathrm{s}, \mathrm{H}-12), 4.49(1 \mathrm{H}, \mathrm{d}, \mathrm{J}=10.0 \mathrm{~Hz}, \mathrm{H}-3), 1.26(3 \mathrm{H}$, s, H-27), 1.17 (3H, s, H-25), 1.09 (3H, s, H-24), $1.03(3 \mathrm{H}$, s, H-26), 0.98 (3H, s, H-30), and $0.91(3 \mathrm{H}, \mathrm{s}, \mathrm{H}-29)$; ${ }^{13} \mathrm{C}$ NMR (100 MHz, Pyr-d5) $\delta_{\mathrm{C}}: 44.9$ (C-1), 74.0 (C-2), 74.3 (C-3), 44.6 (C-4), 47.8 (C-5), 18.8 (C-6), 33.1 (C-7), 40.1 (C-8), 48.4 (C-9), 38.9 (C-10), 24.0 (C-11), 122.7 (C-12), 145.3 (C-13), 42.6 (C-14), 28.6 (C-15), 24.3 (C-16), 46.9 (C-17), 42.3 (C-18), 46.7 (C-19), 31.3 (C-20), 34.5 (C-21), 33.5 (C-22), 65.9 (C-23), 14.7 (C-24), 17.5 (C-25), 17.8 (C-26), 26.5 (C-27), 180.5 (C-28), 33.6 (C-29), 24.1 (C-30), 167.9 (C-1'), 116.4 (C-2'), 144.9 (C-3'), $126.5\left(\mathrm{C}-4^{\prime}\right), 130.8\left(\mathrm{C}-5^{\prime}\right), 117.1$ (C-6'), $161.6\left(\mathrm{C}-7^{\prime}\right), 117.1\left(\mathrm{C}-8^{\prime}\right)$, and $130.8\left(\mathrm{C}-9^{\prime}\right)$.

\section{Cell Lines and Reagents}

For this study, BGC823 and SGC7901 cells (human gastric cancer cell lines) and LO2 cells (a human hepatic cell line) were obtained from the American Type Culture Collection (Rockville, MD) and were cultivated in DMEM supplemented with $10 \%$ foetal bovine serum in a 5\% CO2 humidified atmosphere at $37^{\circ} \mathrm{C}$. Foetal bovine serum, DMEM, trypsin and EDTA were purchased from Gibco; MTT and DMSO were purchased from Sigma; annexin V-fluorescein isothiocyanate (FITC) and propidium iodide (PI) were purchased from BD Biosciences. Antibodies against p21, p53, c-IAP1, c-IAP2, GAPDH, Bcl-2, and Bcl-xL were purchased from Santa Cruz Biotechnology (Santa Cruz, CA). Antibodies against Mcl-1, Bax, Caspase-3, cleaved Caspase-3, Caspase-9, PARP, STAT3, p-Stat3, ATM, p-ATM, Chk2, p-Chk2 were purchased from Cell Signaling Technology (Danvers, MA). RTR-1, derived from Rhodomyrtus tomentosa root and provided by the Institute of Traditional Chinese Medicine and Natural Products of Jinan University, was dissolved in dimethyl sulfoxide (DMSO; Sigma, USA) at $100 \mathrm{mmol} / \mathrm{L}$.

\section{MTT Assay}

Cell growth and viability were measured using an MTT assay. The cells in the logarithmic growth phase were

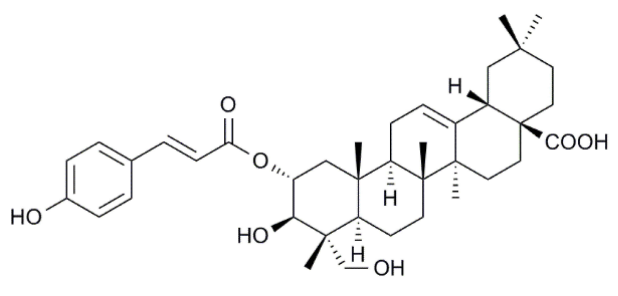

RTR-1

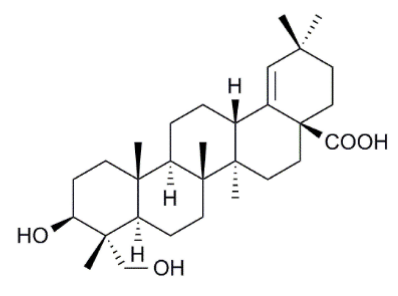

RTR-8

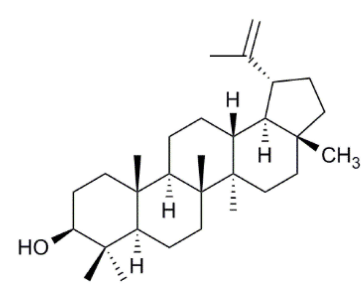

RTR-9

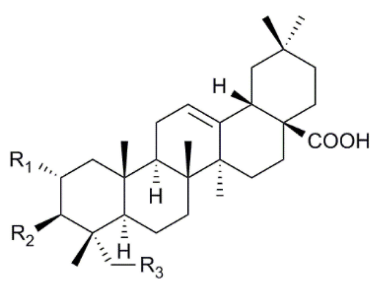

RTR-2 $\mathrm{R}_{1}=\mathrm{OH}, \mathrm{R}_{2}=$ O-trans - - coumaroyl, $\mathrm{R}_{3}=\mathrm{OH}$ RTR-3 $\mathrm{R}_{1}=\mathrm{OH}, \mathrm{R}_{2}=O$ - cis- $p$-coumaroyl, $\mathrm{R}_{3}=0 \mathrm{H}$ RTR-4 $\mathrm{R}_{1}=\mathrm{OH}, \mathrm{R}_{2}=\mathrm{OH}, \mathrm{R}_{3}=\mathrm{OH}$ RTR-5 $\mathrm{R}_{1}=\mathrm{H}, \mathrm{R}_{2}=\mathrm{OH}, \mathrm{R}_{3}=\mathrm{OH}$ RTR-6 $\mathrm{R}_{1}=\mathrm{OH}, \mathrm{R}_{2}=\mathrm{OH}, \mathrm{R}_{3}=\mathrm{H}$

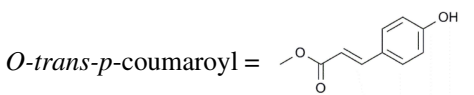

O-cis-p-coumaroyl $={ }^{\circ} Y^{\circ}{ }^{\mathrm{OH}}$

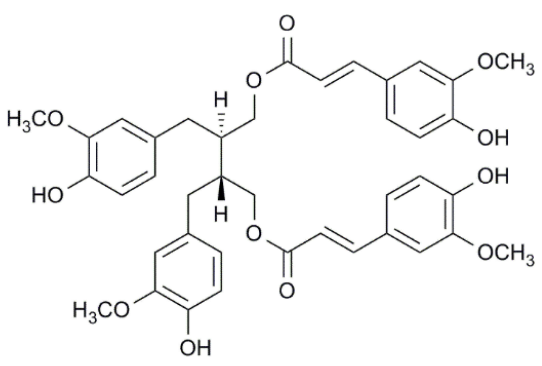

RTR-17

Figure I The chemical structure of RTR-I, RTR-2, RTR-3, RTR-4, RTR-5, RTR-6, RTR-8, RTR-9, and RTR-I7. 
seeded in 96 -well plates at a density of $5.0 \times 10^{3}$ cells per well and incubated overnight. Then, the cells were treated with different concentrations of RTR-1 $(0.78,1.56,3.12$, $6.25,12.5,25$ and $50 \mu \mathrm{mol} / \mathrm{L})$, and DMSO $(0.04 \%)$ was used as the vehicle control ( 5 repeated wells were set up in each group). The cells were incubated in standard culture conditions. Then, $10 \mu \mathrm{L}$ of MTT $(5 \mathrm{mg} / \mathrm{mL})$ was added to each well and the cells were incubated for an additional 4-6 h. The supernatants were then carefully discarded, and $100 \mu \mathrm{L}$ of DMSO was added; the cells were then shaken vigorously for $5 \mathrm{~min}$ to dissolve the purple precipitate. A microplate reader (Bio-Rad Laboratories, Hercules, CA, USA) was used to measure the absorbance at a wavelength of $570 \mathrm{~nm}$. The following formula was used to calculate the inhibition rate of cell proliferation: cell inhibitory rate $=\left(1-\mathrm{A}_{\text {treatment }} / \mathrm{A}_{\text {blank }}\right) \times 100 \%$. Each measurement was performed in triplicate, and each experiment was conducted at least three times.

\section{Colony Formation Assays}

Cells in the logarithmic growth phase were seeded at a density of 500 cells per well in 6-well tissue culture plates and incubated overnight. Then, the cells were treated with different concentrations of RTR-1 $(2,4,8 \mu \mathrm{mol} / \mathrm{L})$, and DMSO (0.04\%) was used as the vehicle control. The cells were incubated for 14 days under standard culture conditions. At the end of the incubation period, the cells were fixed with methanol: acetic acid $=3: 1$ and stained with $0.1 \%(\mathrm{w} / \mathrm{v})$ crystal violet. Megascopic cell colonies were photographed with a Canon camera. Each measurement was taken in triplicate, and each experiment was conducted at least three times.

\section{Cellular ROS Production}

Cells were seeded in six-well plates with $2 \mathrm{~mL}$ in each well. The cells were treated with either RTR-1 for the indicated times, with various concentrations of RTR-1 for $24 \mathrm{~h}$ or pre-incubated with $5 \mathrm{mmol} / \mathrm{L}$ NAC followed by treatment with $40 \mu \mathrm{mol} / \mathrm{L}$ RTR-1 for $24 \mathrm{~h}$ and then incubated with $5 \mu \mathrm{mol} / \mathrm{L}$ (final concentration) CM-H2DCF-DA in the dark for $30 \mathrm{~min}$ at $37^{\circ} \mathrm{C}$. After being washed twice with PBS at $4^{\circ} \mathrm{C}$, the cells were centrifuged and resuspended in PBS. The level of intracellular ROS were detected by flow cytometry with a FACSCalibur system and CellQuest PRO analysis software.

\section{Cell Cycle Distribution}

Cells in the logarithmic growth phase were seeded at a density of $1.0 \times 10^{5}$ cells per well in 6 -well tissue culture plates. Then, the cells were treated with different concentrations of RTR-1 $(10,20$, or $40 \mu \mathrm{mol} / \mathrm{L})$, and DMSO $(0.04 \%)$ was used as the vehicle control. The cells were washed twice with cold PBS and harvested by trypsinization. The cells were washed twice with cold PBS and then fixed in $70 \%$ ethanol overnight at $4^{\circ} \mathrm{C}$. Then, the cells were washed three times with PBS and incubated with PI $(500 \mathrm{~g} / \mathrm{L})$ and RNase for $0.5 \mathrm{~h}$ in the dark. The samples were immediately analysed using a flow cytometer. A total of 10,000 cells was analysed in each sample.

\section{Annexin V-FITC/PI Double-Staining Assay}

Cells in the logarithmic growth phase were seeded at a density of $2.0 \times 10^{5}$ cells per well in 6 -well plates. Then, the cells were treated with various concentrations of RTR-1 $(10,20$, or $40 \mu \mathrm{mol} / \mathrm{L})$, and DMSO $(0.04 \%)$ was used as the vehicle control. After $24 \mathrm{~h}$ of incubation, both the floated and attached cells were collected. The cells were washed twice with ice-cold PBS, resuspended in $200 \mu \mathrm{L}$ of binding buffer, and incubated with $10 \mu \mathrm{L}$ of annexin V-FITC and 5 $\mu \mathrm{L}$ of PI for $15 \mathrm{~min}$ at room temperature in the dark. Then, a flow cytometer was used to analyse the percentage of cells in early and late apoptosis. A total of 10,000 cells was analysed in each sample.

\section{Hoechst 33342 Staining}

Cells in the logarithmic growth phase were seeded at a density of $2.0 \times 10^{5}$ cells per well in 6 -well plates. Then, the cells were treated with various concentrations of RTR-1 $(10,20$, or $40 \mu \mathrm{mol} / \mathrm{L})$, and DMSO $(0.04 \%)$ was used as the vehicle control. After $24 \mathrm{~h}$ of incubation, the cells were stained with $2 \mu \mathrm{g} / \mathrm{mL}$ Hoechst 33342 dye for $5 \mathrm{~min}$. The cells were then washed twice with PBS. The cells were detected at an excitation wavelength of $350 \mathrm{~nm}$ and emission wavelength of $460 \mathrm{~nm}$ by fluorescence microscopy.

\section{Western Blot Analysis}

Cells were seeded at a density of $2.0 \times 10^{5}$ per well in 6-well plates. Then, the cells were treated with various concentrations of RTR-1 (10, 20, and $40 \mu \mathrm{mol} / \mathrm{L})$, and DMSO (0.04\%) was used as the vehicle control. After $24 \mathrm{~h}$ of incubation, the cells were collected and washed twice with ice-cold PBS. Then, the cells were lysed in buffer on ice for $15 \mathrm{~min}$ and centrifuged at $12,000 \times \mathrm{g}$ for $10 \mathrm{~min}$ at $4^{\circ} \mathrm{C}$. The cell proteins were extracted, and the protein concentration was determined using a BCA assay. A total of $25 \mu \mathrm{g}$ of protein was denatured by the addition of $5 \times$ reducing sample buffer after incubation for $5 \mathrm{~min}$ at $100^{\circ} \mathrm{C}$, and then, the protein samples $(25 \mu \mathrm{g})$ were 
loaded in each well of an 8-15\% polyacrylamide gel, separated by SDS-PAGE and transferred to a polyvinylidene fluoride (PVDF) membrane (Millipore, Bedford, MA, USA). After the membranes were blocked with $5 \%$ skimmed milk, the membranes were incubated overnight at $4{ }^{\circ} \mathrm{C}$ with the appropriate antibody. Then, the membranes were washed three times for $10 \mathrm{~min}$ each time with TBST (10 mM Tris, 100 $\mathrm{mM} \mathrm{NaCl}$, and $0.1 \%$ Tween 20 ) and incubated for $2 \mathrm{~h}$ at room temperature with a secondary antibody conjugated to horseradish peroxidase. After the membrane was washed three times in TBST, the bound antibody complex was detected using an ECL chemiluminescence reagent and XAR film (Kodak) as described previously.

\section{Statistical Analyses}

The results are expressed as the mean \pm standard error (SE) of 3 independent experiments. Student's $t$-tests were used to determine the significance between the control and test groups. $\mathrm{P}<0.05$ was considered significant.

\section{Results}

\section{Biological Activity}

To verify the potential anticancer properties of the RTR compounds isolated from Rhodomyrtus tomentosa, we first tested whether the compounds could inhibit the proliferation of various cancer cells. To this end, gastric cancer (BGC823 and SGC7901) cells, hepatocellular cancer (SMMC7721) cells and malignant melanoma (SK-Mel-110) cells were treated with increasing concentration of RTR compounds, and the extent of cell proliferation was determined with an MTT assay. As shown in Figure 2A-D, most RTR compounds could partially inhibit cell proliferation in a dose-dependent manner in cancer cell lines. Furthermore, the half maximal inhibitory concentration (IC50) valuesof RTR-1 on BGC823, SGC7901, SMMC7721 and SK-Mel-110 cells at $48 \mathrm{~h}$ were $15.43 \pm 0.47,16.80 \pm 0.4,20.89 \pm 0.84$ and $12.66 \pm 0.3 \mu \mathrm{mol} /$ $\mathrm{L}$, respectively (Figure 2E). These data suggest that RTR-1 may be a new source of anticancer compounds.

\section{Growth Inhibition Effects of RTR-I on Gastric Cancer Cells and LO2 Cells}

To investigate the anticancer effect of RTR-1 on gastric cancer proliferation and viability, we selected normal liver cancer (LO2) cells and cells from two human gastric cancer cell lines (BGC823 and SGC7901) and treated them with various concentrations of RTR-1 for $24 \mathrm{~h}, 48 \mathrm{~h}$ and $72 \mathrm{~h}$ (Figure 3A-C). Our results showed that RTR-1 treatment decreased the viability of BGC823 and SGC7901 cells in a dose- and time-dependent manner. Interestingly, the effect of RTR-1 on LO2 cells was not notable. In addition, the IC50 values of RTR-1 for LO2 cells at $24 \mathrm{~h}, 48 \mathrm{~h}$ and 72 $\mathrm{h}$ were $154.36 \pm 5.26,70 \pm 3.33$, and $46.82 \pm 4.45 \mu \mathrm{mol} / \mathrm{L}$,
A

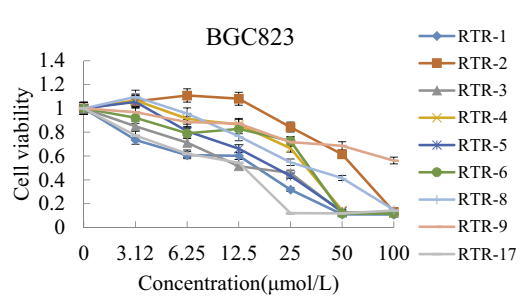

C

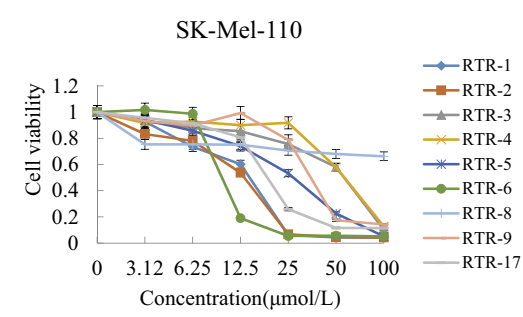

B

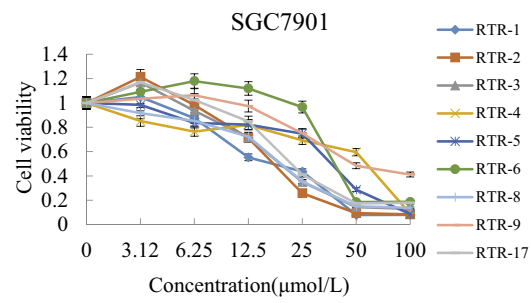

E

D

SMCC7721

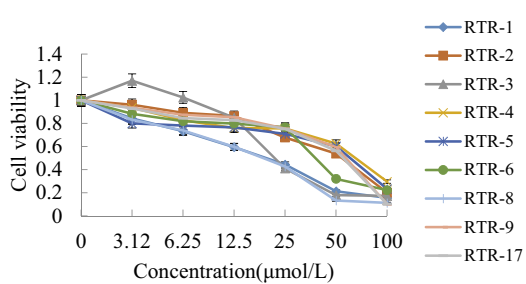

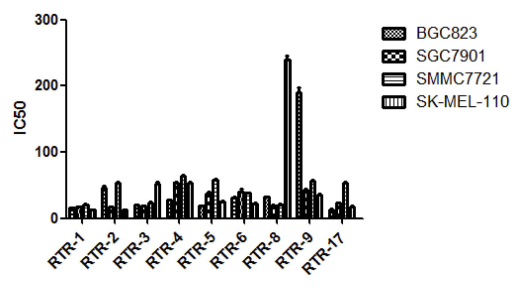

Figure 2 Inhibitory activities of RTRs in some cancer cell lines. (A) Proliferative effects of the RTR compounds on the BGC823 cells at $48 \mathrm{~h}$. (B) Proliferative effects of the RTRs on the SGC790 I cells at 48 h. (C) Proliferative effects of RTRs on the SK-Mel-I I0 at 48 h. (D) Proliferative effects of the RTRs on the SMMC772I cells at 48 h. Each value represents three independent experiments. (E) The IC50 values of RTR compounds for the BGC823, SGC790I, SK-Mel-I I0 and SMMC772I cells at 48 h. 
A

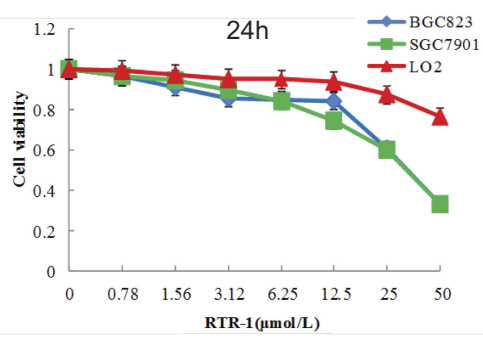

D

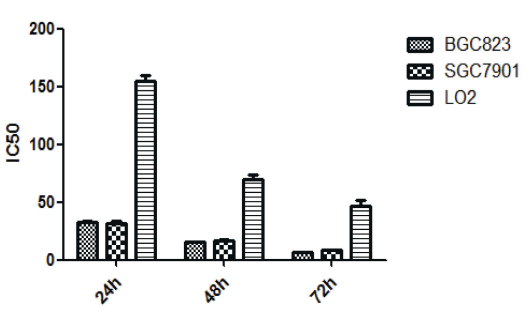

B

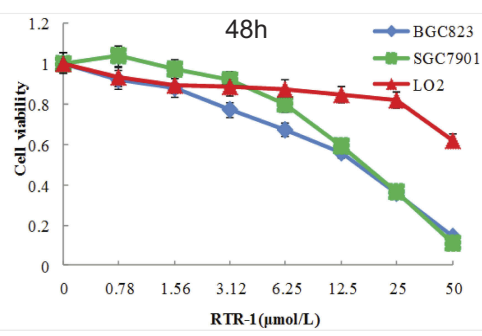

C

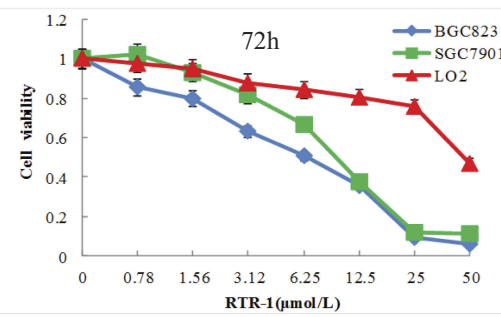

E

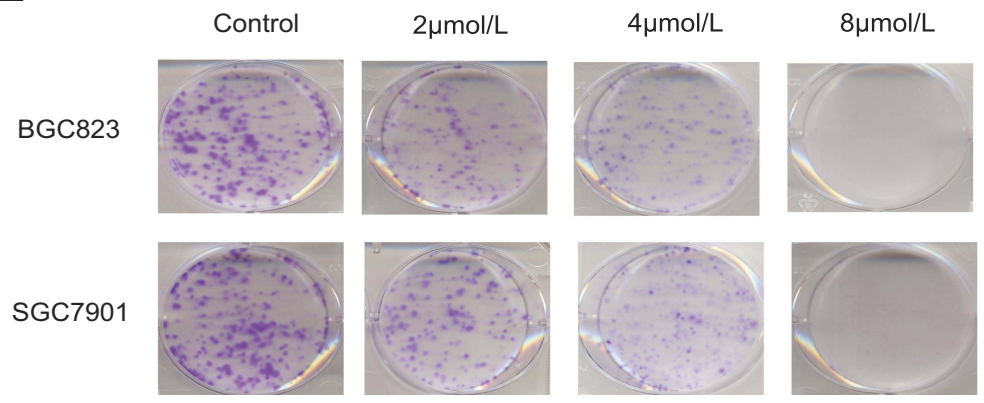

Figure 3 Inhibitory activities of RTR-I in the BGC823, SGC790I and LO2 cells. (A-C) Proliferative effects of RTR-I on the BGC823, SGC790I, and LO2 cells. Inhibition of cell proliferation was determined with MTT assays, and the IC50 value was calculated as described in the materials and methods. (D) IC50 values of RTR-I for the BGC823, SGC790I and LO2 cells in vitro. (E) BGC823 and SGC790I cells were treated with different concentrations of RTR-I for I4 days. Each value represents three independent experiments.

respectively. The IC50 values of RTR-1 on BGC823 cells at $24 \mathrm{~h}, 48 \mathrm{~h}$ and $72 \mathrm{~h}$ were $32.47 \pm 1.23,15.43 \pm 0.47$, and 6.40 $\pm 0.03 \mu \mathrm{mol} / \mathrm{L}$, respectively. The IC50 values of RTR-1 on SGC7901 cells at $24 \mathrm{~h}, 48 \mathrm{~h}$ and $72 \mathrm{~h}$ were $32.10 \pm 1.09,16.80$ $\pm 0.4, \quad 8.38 \pm 0.56 \mu \mathrm{mol} / \mathrm{L}, \quad$ respectively (Figure 3D). Furthermore, the colony formation assays showed that RTR-1 could dramatically inhibit colony formation in a concentration-dependent manner, as indicated by fewer and smaller colonies in the drug-treated group (Figure 3E). Taken together, these results demonstrate that RTR-1 exhibits significant anticancer activity by inhibiting cell proliferation and viability.

\section{RTR-I Induces Cell Cycle Arrest Through ATM-Chk2-P53-P2I Signaling Pathway}

Cell proliferation inhibition is often strongly associated with changes in cell cycle progression; ${ }^{10}$ therefore, we evaluated the distribution of BGC823 and SGC7901 cells in cell cycle. After treatment with RTR-1 for 24 $\mathrm{h}$, the cell cycle distribution changed significantly, with a remarkable increase in cell population in $\mathrm{G} 2 / \mathrm{M}$ phase and a decrease in cell population in $\mathrm{S}$ phase (Figure 4A). For example, the fraction of BGC823 cells in G2/ $M$ phase increased from $13.5 \%$ (DMSO treated) to $20.8 \%, 24.5 \%$ and $32.1 \%$ for cells treated with 10,20 , and $40 \mu \mathrm{mol} / \mathrm{L}$ RTR-1, respectively. In summary, the cell cycle distribution results indicate that cell cycle is mainly arrested in $\mathrm{G} 2 / \mathrm{M}$ phase.

Cyclins and CDK complexes are of great significance in regulating cell cycle progression, with different CDKs and cyclins governing different phases of the cell cycle. In gastric cells, the Cyclin $\mathrm{B} / \mathrm{cdc} 2$ complex has an important function in controlling the $\mathrm{G} 2 / \mathrm{M}$ transition. However, the function of the Cyclin B/cdc2 complex can be reversed by p21 and Myt-1, as Myt-1 phosphorylates Tyr15 and Thr14 of CDK1 (cdc2) and inhibits its activity. We used a Western blot analysis to determine the expression of cell cycle-related proteins, namely, cyclins, CDKs, CKIs, Myt-1 and p-Wee1. As shown in Figure 4B and C, the expression levels of Myt-1, Cyclin B1, p-cdc2 (Tyr15) and p-Wee1 were markedly increased, while Cyclin D1, CDK1 and CDK4 were noticeably reduced, and the expression levels of Cyclin E and Cyclin A remained unchanged in the RTR-1-treated groups compared to the levels in the control groups. It has been reported that, in response to DNA damage, cells activate a signaling network to arrest the cell cycle and facilitate DNA repair, which inhibits cell proliferation. ${ }^{11}$ To determine how RTR-1 induced cell cycle arrest in the G2/M phase, we examined the expression levels of the proteins involved in the ATM-Chk2-p53- 


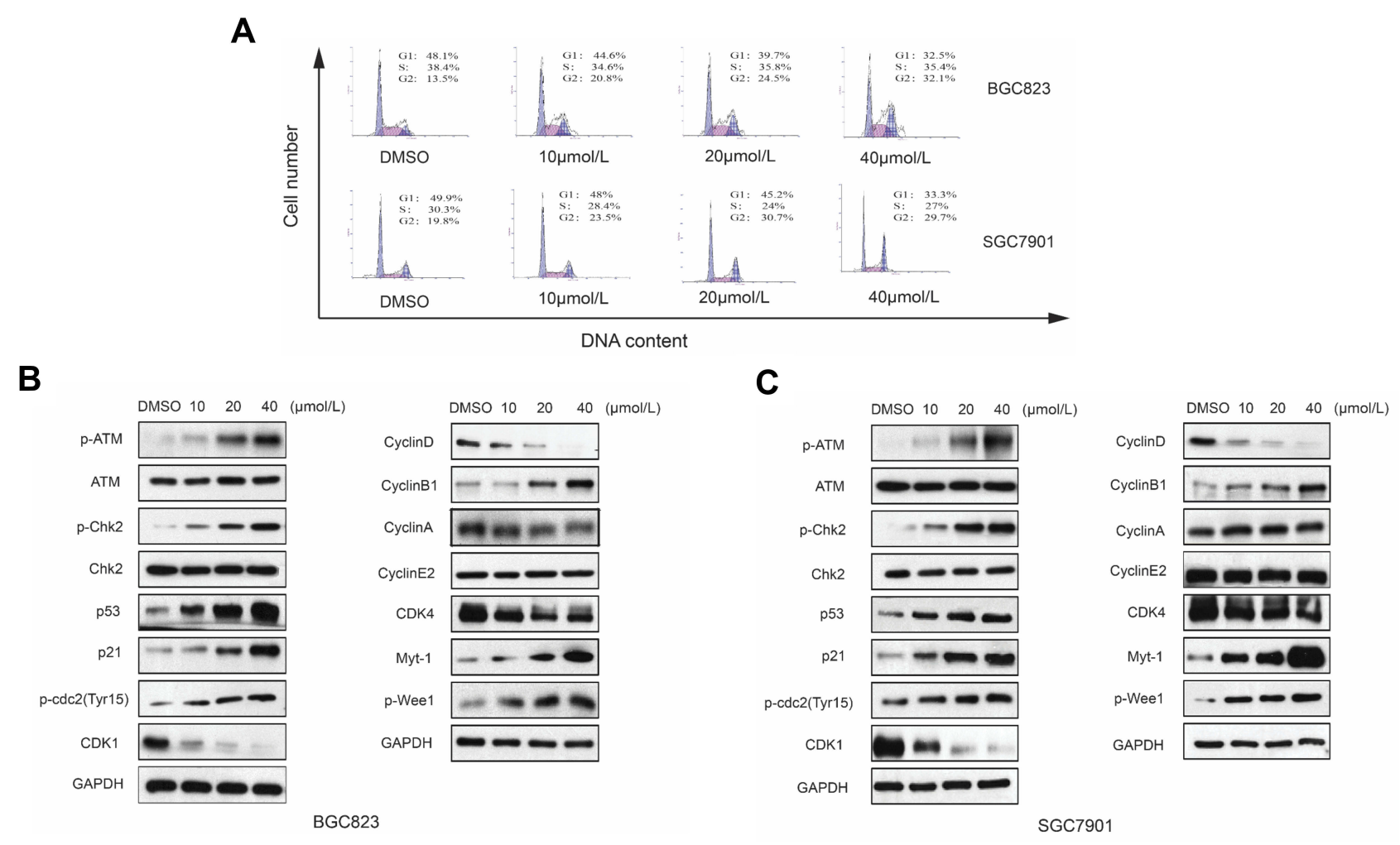

Figure 4 Effect of RTR-I on the induction of cell cycle arrest in the BGC823 and SGC790I cells. (A) BGC823 and SGC790I cells were treated with various concentrations of RTR-I for $24 \mathrm{~h}$. The expression of the cell cycle-associated proteins in the BGC823 cells (B) and the SGC790I cells (C) was analysed by Western blotting. Data represent one of three experiments that yielded similar results.

p21 signaling pathways using Western blotting. We found that the expression levels of p-ATM, p-Chk2, p53, and p21 were increased (Figure 4B and C). Thus, these data further demonstrate that RTR-1 induces cell cycle arrest in the G2/M phase through the ATM-Chk2-p53-p21 signaling pathway in BGC823 and SGC7901 cells.

Overall, these results indicate that RTR-1 inhibits cell proliferation by inducing cell cycle arrest in the $\mathrm{G} 2 / \mathrm{M}$ phase through the ATM-Chk2-p53-p21 signaling pathway in BGC823 and SGC7901 cells.

\section{RTR-I Promotes Apoptosis via the Caspase Pathway}

Phosphatidylserine (PS) translocation to the cell surface is an indicator of early apoptosis. To confirm whether the growth inhibition of RTR-1 was caused by apoptosis in vitro, we first used an annexin V-FITC/PI doublestaining assay to detect the number of apoptotic BGC823 and SGC7901 cells that had been treated with $0.04 \%$ DMSO or 10,20 and $40 \mu \mathrm{mol} / \mathrm{L}$ RTR-1 for 24 h. As illustrated in Figure 5A, the percentage of apoptotic cells increased with increasing RTR-1 concentration. Moreover, the apoptosis rate reached $41.8 \%$ in the RTR-1 treated BGC 823 cell, compared to $1.2 \%$ for the control cells, while it reached $46.2 \%$ for the RTR-1 treated SGC7901 cells compared to $2.2 \%$ for the control cells. Furthermore, Hoechst 33342 staining showed that the BGC823 and SGC7901 cells treated with increasing RTR-1 concentration showed significant apoptotic changes; for example, the cytoskeletal structures were damaged, and the cells became round and shrunken with nuclear fragmentation and aggregation (Figure 5B). In addition, we were further inspired to explore how RTR-1 is involved in the activation of apoptosis. Caspase- 9 is a major caspase member that mediates intrinsic apoptosis, while caspase- 3 is one of the key effectors in the execution of the downstream apoptotic pathway. ${ }^{12}$ After treatment with RTR-1 for 24 $h$, upregulated level of cleaved caspase- 3 and downregulated levels of PARP, caspase- 3 and caspase-9 were observed in the BGC823 and SGC7901 cells (Figure 5C). Taken together, these results indicate that RTR-1 inhibits cell proliferation by inducing apoptosis through the caspase pathway in BGC823 and SGC7901 cells. 
A

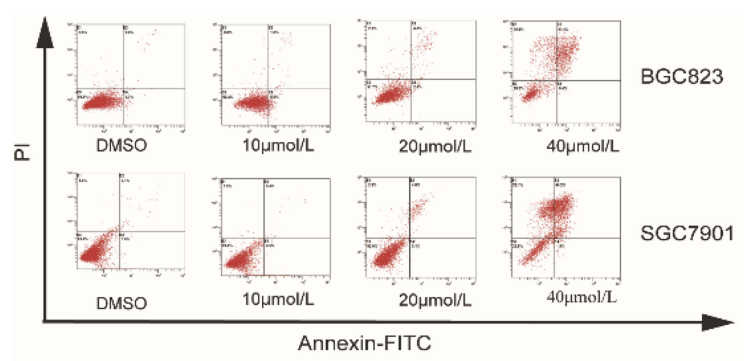

C

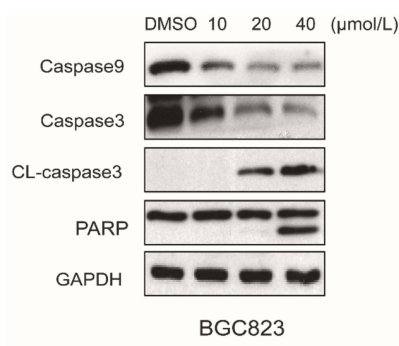

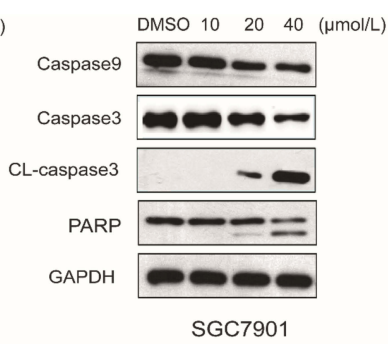

B

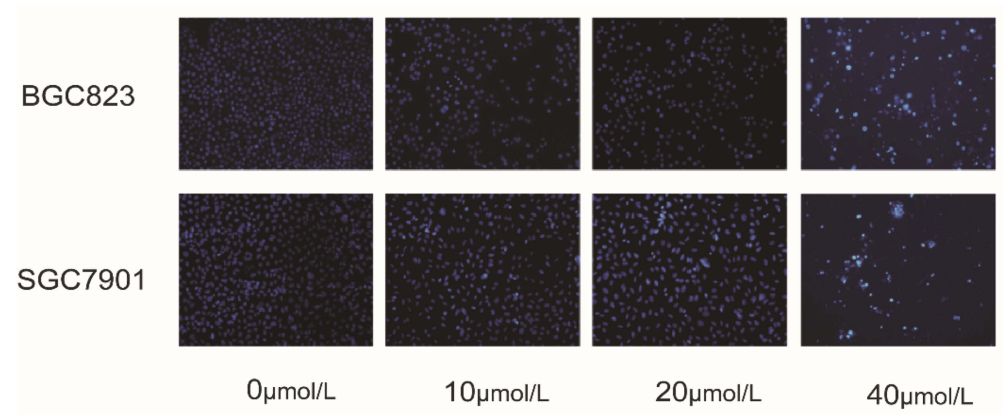

Figure 5 Effect of RTR-I on the induction of apoptosis in the BGC823 and SGC790I cells. (A) BGC823 and SGC790I cells were treated with various concentrations of RTR-I for $24 \mathrm{~h}$ and stained with annexin V-FITC and PI to distinguish and quantitatively determine the percentages of apoptotic cells. (B) BGC823 and SGC790I cells were treated with various concentrations of RTR-I for $24 \mathrm{~h}$ and analysed with Hoechst 33342 staining. (C) The expression of apoptosis-related proteins in the BGC823 and SGC790I cells was analysed by Western blotting. Data represent one of three experiments that yielded similar results.

\section{Effects of RTR-I on the Expression of IAPs and $\mathrm{Bcl}-2$ Family Proteins}

The generation of reactive oxygen species (ROS) has been reported to play an important role in the cell cycle. ${ }^{13}$ In this study, we found that the level of reactive oxygen species increased when BGC823 and SGC7901 cells were treated with RTR-1 in a dose- and time-dependent manner (Figure 6A). Additionally, the Bcl-2 family of proteins has great significance with regard to apoptosis. Bcl-2 family proteins, including the pro-apoptotic proteins Bax and Bad and the anti-apoptotic proteins Bcl-2, Bcl-xl and Mcl-1, were also investigated. As shown in Figure 6B, RTR-1 treatment significantly reduced the expression of Mcl-1 and Bcl-2 and enhanced the expression of Bax and Bad but did not change the expression of Bcl-xl. These results suggest that the apoptosis induced by RTR-1 occurs through the mitochondriamediated pathway in BGC823 and SGC7901 cells. Furthermore, the apoptosis induced by overexpression of procaspases 3, 7 or 9 can also be suppressed by the co-expression of XIAP, c-IAP1, c-IAP2 and survivin. In this study, we found that the expression of XIAP, c-IAP1 and c-IAP2 decreased and that the expression of survivin decreased in BGC823 cells, while the expression of survivin remained unchanged in SGC7901 cells (Figure 6C).

These findings suggest that ROS generation is the key regulator of RTR-1-induced cell cycle arrest and apoptosis induced by RTR-1 through the mitochondria-mediated and IAP pathways in BGC823 and SGC7901 cells.

\section{RTR-I Induces ER Stress and Inhibits the STAT3 Pathway}

It has been found that endoplasmic reticulum (ER) stress can trigger apoptotic signaling. To investigate whether RTR-1-induced apoptosis is mediated by ER stress, we used Western blot analysis to determine the level of ER stress-associated proteins in BGC823 and SGC7901 cells. After treatment with different doses of RTR-1 for $24 \mathrm{~h}$, the levels of IRE1 $\alpha$, Erol-L $\alpha$, CHOP, PERK and BiP were upregulated, while there was less effect on the expression of PDI (Figure 7A). Thus, these data demonstrate that RTR1 promotes apoptosis by inducing ER stress in BGC823 and SGC7901 cells.

In addition, signal transducer and activator of transcription 3 (STAT3), an oncogenic transcription factor, promotes 
A

A

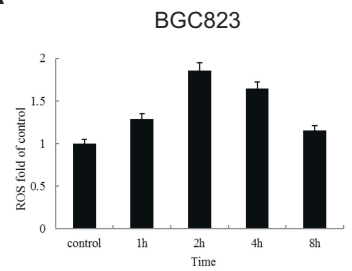

B

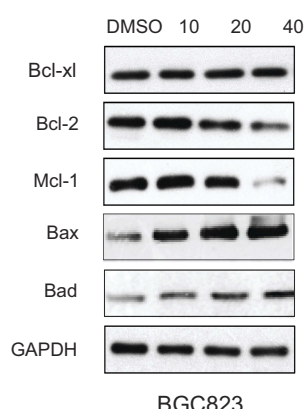

SGC7901

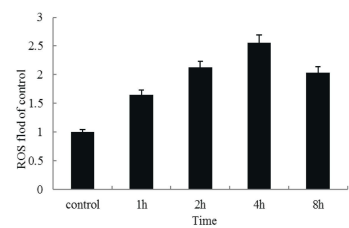

$(\mu \mathrm{mol} / \mathrm{L})$

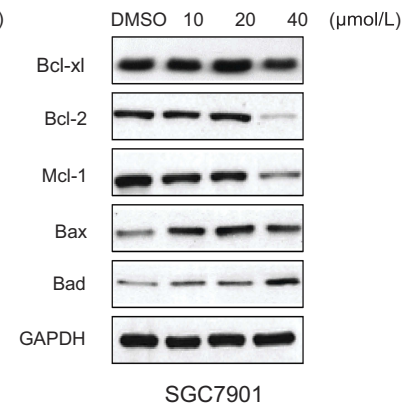

BGC823

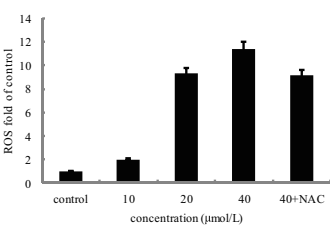

C

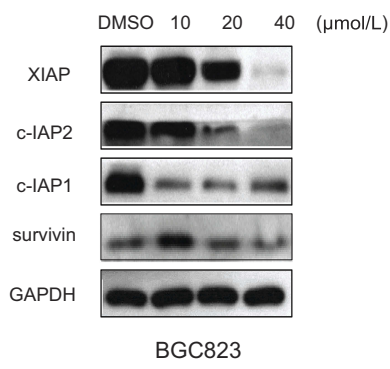

SGC7901
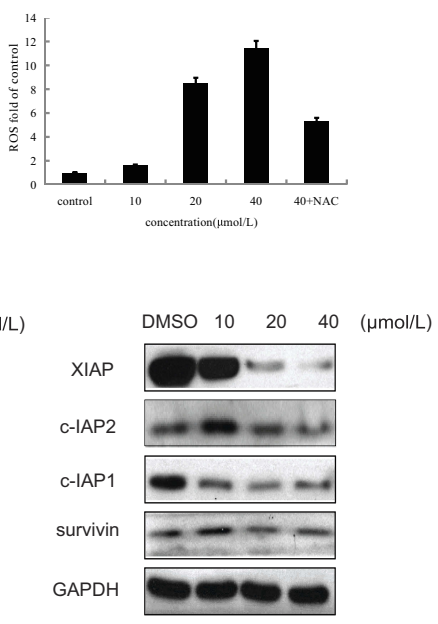

SGC7901

Figure 6 Effect of RTR-I on the expression of IAP and Bcl-2 family proteins. (A) BGC823 and SGC790I cells were treated with $20 \mu$ mol/L RTR-I for different time periods (hours) and treated with different concentrations of RTR-I for $24 \mathrm{~h}$ in the presence or absence of NAC. (B) Bcl-2 family proteins were analysed by Western blotting. (C) IAP family proteins were analysed by Western blotting. Data represent one of three experiments that yielded similar results.

A

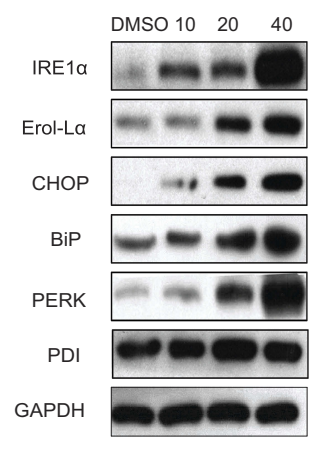

BGC823
C
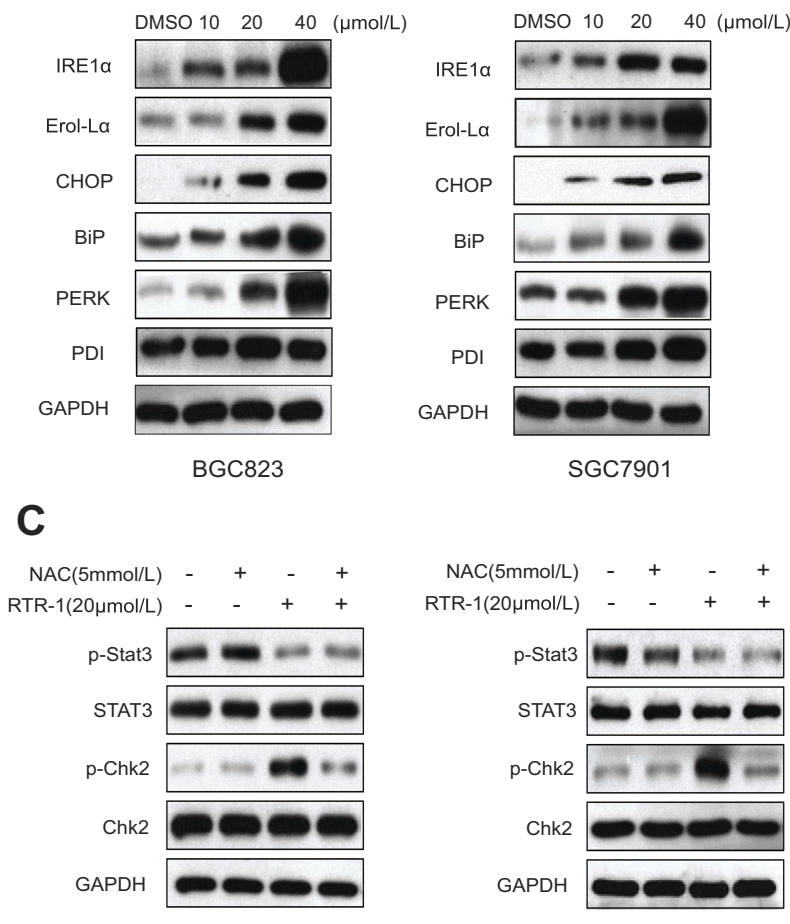

BGC823

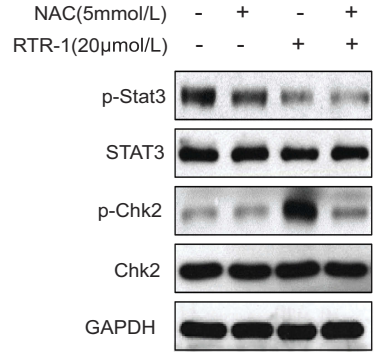

SGC7901
B

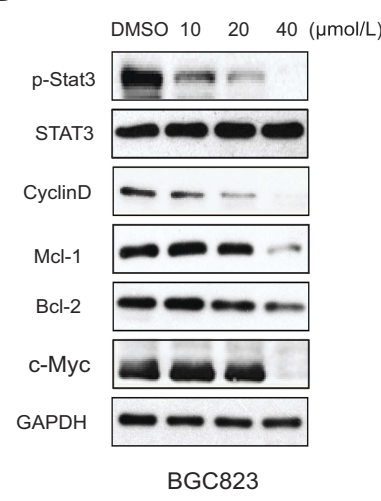

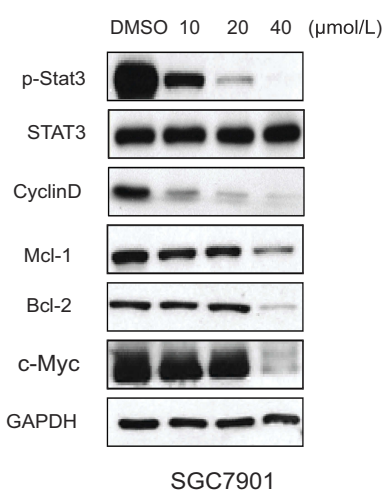

Figure 7 Effect of RTR-I on the ER stress and STAT3 pathways in the BGC823 and SGC790I cells was analysed by Western blotting. (A) ERS-related proteins were analysed by Western blotting. (B) STAT3-related proteins were analysed by Western blotting. (C) The effect of ROS on the STAT3 signal pathway and cell cycle-associated proteins in the BGC823 and SGC790I cells was analysed by Western blotting.

tumorigenesis by regulating the expression of various target genes, including cell cycle regulators, angiogenic factors and anti-apoptosis genes. ${ }^{14}$ To study whether RTR-1 modulated
STAT3 activation, BGC823 and SGC7901 cells were treated with different concentrations of RTR-1, and then, STAT3 and STAT3 phosphorylation were examined by Western 
blotting. We found that p-STAT3 in BGC823 and SGC7901 cells was substantially reduced upon RTR-1 treatment (Figure 7B). Moreover, we analysed the effect of RTR-1 on some proteins that mediate anti-apoptotic signals downstream of STAT3 activation, namely, Cyclin D1, c-Myc, Bcl2 and Mcl-1. As shown in Figure 8B, RTR-1 strongly inhibited Cyclin D1, c-Myc, Bcl-2 and Mcl-1 protein expression in BGC823 and SGC7901 cells. Therefore, RTR-1 effectively inhibits the STAT3 pathway in BGC823 and SGC7901 cells.

Furthermore, ROS may play roles in cytokine activation of JAK kinases as well as STAT3 and STAT5 expression and cell cycle. ${ }^{15}$ To further confirm the relationship between ROS and STAT3 and the cell cycle distribution, the expression of p-Stat 3 and p-Chk2 was examined by Western blot analysis after N-acetyl-L-cysteine (NAC) pretreatment. Our results show that pretreatment with NAC significantly reversed the RTR-1-induced increase in p-Chk2 in BGC823 and SGC7901 cells. However, the expression of p-Stat3 was less affected after pretreatment with NAC in BGC823 and SGC7901 cells (Figure 7C). These data further demonstrate that ROS play an essential role in inducing cell cycle arrest in BGC823 and SGC7901 cells.

Thus, our results indicate that RTR-1 inhibits gastric cancer cell growth via the promotion of apoptosis by inducing ER stress and inhibiting the STAT3 signaling pathway.

\section{Discussion}

Gastric cancer is associated with high morbidity and mortality worldwide. Chemotherapy is a cornerstone of the treatments for gastric cancer; however, less than $60 \%$ of patients receive salvage therapy in clinical practice. Moreover, gastric cancer has poor outcomes with regard to both surgical resection and chemotherapy. ${ }^{16}$ Therefore, the search for an effective chemotherapeutic drug that induces minimal toxicity has become an important part of the search for gastric cancer treatments. Additionally, studies on the activities of compound extracts from myrtle leaves, stems and flowers have become the focus of research. It has been discovered that compound extracts from myrtle leaves, stems and flowers exhibit antioxidant effects $^{17}$ and potential antibiotic and anti-infective effects. ${ }^{18}$ However, it remains unclear whether RTR-1, a compound recently isolated from Rhodomyrtus tomentosa, can inhibit the proliferation of gastric cancer cells.

In this study, we first investigated the inhibitory effect of RTR-1 on the proliferation of BGC823, SGC7901 and LO2 cells by MTT assay and found that RTR-1 had a relatively weak inhibitory effect on the proliferation of LO2 cells compared to the significant time- and dosedependent growth inhibition effects it had on BGC823 and SGC7901 cells. The IC50 values of RTR-1 on LO2 cells at $24 \mathrm{~h}, 48 \mathrm{~h}$ and $72 \mathrm{~h}$ were $154.36 \pm 5.26,70 \pm 3.33$, and $46.82 \pm 4.45 \mu \mathrm{mol} / \mathrm{L}$, respectively. The IC50 values of RTR-1 on BGC823 cells at $24 \mathrm{~h}, 48 \mathrm{~h}$ and $72 \mathrm{~h}$ were 32.47 $\pm 1.23,15.43 \pm 0.47$, and $6.40 \pm 0.03 \mu \mathrm{mol} / \mathrm{L}$, respectively. The IC50 values of RTR-1 on SGC7901 cells at $24 \mathrm{~h}, 48$ $\mathrm{h}$ and $72 \mathrm{~h}$ were $32.10 \pm 1.09,16.80 \pm 0.4$, and $8.38 \pm 0.56$ $\mu \mathrm{mol} / \mathrm{L}$, respectively. These results reveal that RTR-1 inhibits the proliferation of BGC823 and SGC7901 cells.

Cell cycle plays a crucial role in regulation of cell growth, differentiation, senescence and apoptosis. Cell

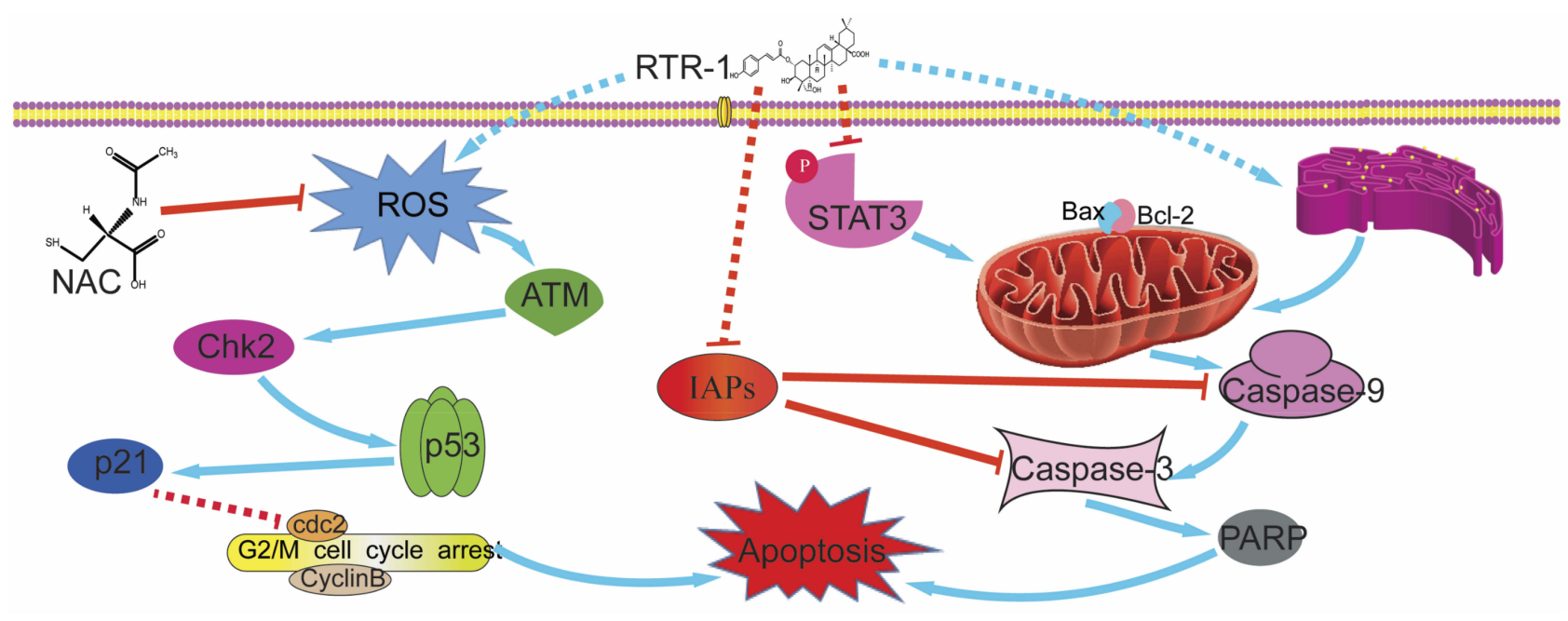

Figure 8 Schematic model for the ability of RTR-I to induce cell cycle arrest and apoptosis. 
cycle progression is regulated through major checkpoints of $\mathrm{G} 1 / \mathrm{S}$ or $\mathrm{G} 2 / \mathrm{M}$ phase. Additionally, cdc2/Cyclin A and cdc2/Cyclin B complex promote the G2/M transition. Phosphorylation of CDK1 (cdc2) on Tyr15 and Thr14 is known to be performed by the Weel and Myt1 protein kinases. ${ }^{19}$ Moreover, cdc2 is phosphorylated at Tyr15 and Thr14 by Wee1 and Myt1, which induces cell cycle arrest in $\mathrm{G} 2 / \mathrm{M}$ phase. $^{20}$ Indeed, a significant population of BGC823 and SGC7901 cells was arrested in G2/M phase after treatment with RTR-1 (Figure 4A). Western blot assays also showed that the expression levels of Cyclin D1, CDK1 (cdc2) and CDK4 were dramatically reduced after $24 \mathrm{~h}$ of RTR-1 treatment (Figure 4B and C). However, the expression levels of Cyclin E and Cyclin A were unchanged, and the expression levels of Myt-1, p-Wee1, Cyclin B1 and p-cdc2 (Tyr15) increased after 24 h of RTR-1 treatment (Figure 4B and C). This observation confirms that the induction of cell cycle arrest in $\mathrm{G} 2 / \mathrm{M}$ phase is partially responsible for the inhibited proliferation of gastric cancer cells.

ROS could be responsible for DNA damage and, accordingly, for the activation of the G2/M DNA damage checkpoint signaling pathway. ${ }^{21,22}$ Indeed, we found that the level of reactive oxygen species in BGC823 and SGC7901 cells increased significantly with RTR-1 treatment in a dose- and time-dependent manner (Figure 6A). The cell cycle checkpoints and DNA repair mechanisms constitute the first line of defence against DNA damage. Western blot analysis showed that the expression levels of p-ATM, p-Chk2, p53, and p21 were increased (Figure 4B and $\mathrm{C}$ ). In addition, we found that $5 \mathrm{mmol} / \mathrm{L} \mathrm{NAC}$ can reverse the level of ROS production (Figure 6A) and upregulate the expression level of p-Chk2 (Figure 7C). Therefore, ROS play significant roles in arresting the cell cycle in BGC823 and SGC7901 cells.

STAT3 has been shown to be involved in the process of cell proliferation, cell differentiation and cell survival and, therefore, plays an important role in tumorigenesis, which is mediated through the regulation of various downstream target genes, including c-Myc, JunB, Mcl-1, survivin, Bcl2, Cyclin D1, MMP-2 and vascular endothelial growth factor (VEGF). ${ }^{23,24}$ Previous studies have established that STAT3 may have a therapeutic effect by preventing gastric cancer, and the inhibition of activated STAT3 could reverse the resistance to chemotherapy agents of human gastric cancer cells. $^{25}$ In this study, we found that the STAT3 signaling pathway was inhibited by RTR-1 and, moreover, that the expression level of p-STAT3 and the downstream related proteins related to it, including c-Myc, Mcl-1, Bcl-2 and Cyclin D1, were decreased. Thus, these data demonstrate that RTR-1 inhibits cell proliferation by promoting apoptosis through the inhibition of STAT3 pathway in BGC823 and SGC7901 cells.

Additionally, it is generally thought that intracellular ROS generation mediates cell cytotoxicity and triggers cell death in cancer cells. ${ }^{26,27}$ Moreover, in normal physiological conditions, NAC has less effect on cancer cells as there is a bit of ROS generation in cells. On the contrary, ROS generation dramatically promotes cell cytotoxicity in cancer cells after drugs (ROS inducer) treatment. When cancer cells are co-cultured with drugs and NAC, NAC eliminates ROS and limits cell apoptosis, promoting cell viability. ${ }^{28,29}$ Increasing evidence suggests that the downstream of ROS may be many kinds of signal protein, such as STAT3, JNK, p38, Bcl-2 and so on, which are controlled by ROS generation and promote cell apoptosis. $^{30-33}$ In the present study, RTR-1 increased the accumulation of ROS in a dose- and time-dependent manner (Figure 6A). Furthermore, the NAC blocking experiment showed that ROS-dependent cell cycle arrest and cell apoptosis are mediated by ATM-Chk2-p53-p21 signaling pathway, and do not depend on JAK-STAT3 signaling pathway (Figure 7C).

ER stress activates a set of signaling pathways collectively termed the unfolded protein response (UPR). ${ }^{34}$ CHOP reportedly regulates energy metabolism, cellular proliferation, and differentiation. Furthermore, ER oxidase $1 \alpha$ (Erol-L $\alpha$ ), a CHOP transcriptional target, plays an essential role in inducing the oxidation of the ER lumen. $^{35}$ In addition, the CHOP-Erol-L $\alpha$ pathway can induce pro-apoptotic oxidative stress in the cytoplasm. ${ }^{36}$ The activation of PERK, generated by the dissociation of GRP78 from PERK, leads to the induction of CHOP, which plays an important role in the switch from prosurvival to pro-death signaling. ${ }^{36}$ Additionally, it was reported that IRE1 $\alpha$, a rheostat capable of regulating cell fate in UPR signaling pathways, ${ }^{37}$ can be regulated by BiP, which is combined with or separated from IRE1 $\alpha$. BiP inhibits IRE1 $\alpha$ activity by binding to it in the absence of stress. $^{38}$ Our current study shows that Erol-L $\alpha$, CHOP, PERK and BiP are increased under the ER stress induced by RTR-1 in gastric cancer cells, inducing the ER stress signaling pathway in BGC823 and SGC7901 cells. Therefore, it is not surprising that the inhibition of gastric cell proliferation is also associated with the induction of 
ER stress with RTR-1 treatment in BGC823 and SGC7901 cells.

Taken together, these results demonstrate that RTR-1 inhibits cell cycle progression by the ATM-Chk2-p53-p21 pathway and induces apoptosis by activating ER stress and inhibiting the STAT3 pathway in BGC823 and SGC7901 cells (Figure 8).

\section{Conclusion}

In summary, our findings indicate that RTR-1 inhibits the proliferation of gastric cancer (BGC823 and SGC7901) cells by blocking cell cycle at $\mathrm{G} 2 / \mathrm{M}$ phase through the ATM-Chk2-p53-p21 signaling pathway and inducing cell apoptosis by inhibiting the STAT3 signaling pathway and activating ER stress. Thus, RTR-1 has good potential as a promising drug candidate for the treatment of gastric cancer.

\section{Acknowledgments}

The study was supported by Science and Technology Planning Project of Guangdong Province, Grant No. 2018B030320007; Science and Technology Planning Project of Guangzhou, China, Grant/Award Number: 201607010372; and the National Natural Science Foundation of China, 81673319 .

\section{Author Contributions}

All authors contributed to data analysis, drafting or revising the article, gave final approval of the version to be published, and agree to be accountable for all aspects of the work.

\section{Disclosure}

The authors report no conflicts of interest in this work.

\section{References}

1. Ferlay J, Shin HR, Bray F, Forman D, Mathers C, Parkin DM. Estimates of worldwide burden of cancer in 2008: GLOBOCAN 2008. Int J Cancer. 2010;127(12):2893-2917. doi:10.1002/ijc.25516

2. Jemal A, Center MM, DeSantis C, Ward EM. Global patterns of cancer incidence and mortality rates and trends. Cancer Epidemiol Biomarkers Prev. 2010;19(8):1893-1907. doi:10.1158/1055-9965. EPI-10-0437

3. Zhao ZS, Wang YY, Chu YQ, Ye ZY, Tao HQ. SPARC is associated with gastric cancer progression and poor survival of patients. Clin Cancer Res. 2010;16(1):260-268. doi:10.1158/1078-0432.CCR-091247

4. Fesik SW. Promoting apoptosis as a strategy for cancer drug discovery. Nat Rev Cancer. 2005;5(11):876-885. doi:10.1038/nrc1736

5. Cragg GM, Newman DJ. Plants as a source of anti-cancer agents. $J$ Ethnopharmacol. 2005;100(1-2):72-79. doi:10.1016/j.jep.2005. 05.011
6. Saising J, Voravuthikunchai SP. Anti propionibacterium acnes activity of rhodomyrtone, an effective compound from Rhodomyrtus tomentosa (Aiton) Hassk. leaves. Anaerobe. 2012;18(4):400-404. doi:10.1016/j.anaerobe.2012.05.003

7. Lavanya G, Voravuthikunchai SP, Towatana NH. Acetone extract from Rhodomyrtus tomentosa: a potent natural antioxidant. Evid Based Complement Alternat Med. 2012;2012:535479. doi:10.1155/ 2012/535479

8. Srisuwan S, Tongtawe P, Srimanote P, Voravuthikunchai SP, Planet PJ. Rhodomyrtone modulates innate immune responses of THP-1 monocytes to assist in clearing methicillin-resistant Staphylococcus aureus. PLoS One. 2014;9(10):e110321. doi:10.1371/journal.pone.0110321

9. Chorachoo J, Saeloh D, Srichana T, et al. Rhodomyrtone as a potential anti-proliferative and apoptosis inducing agent in $\mathrm{HaCaT}$ keratinocyte cells. Eur J Pharmacol. 2016;772:144-151. doi:10.1016/j.ejphar.2015. 12.005

10. Hanahan D, Weinberg RA. Hallmarks of cancer: the next generation. Cell. 2011;144(5):646-674. doi:10.1016/j.cell.2011.02.013

11. Grady WM, Carethers JM. Genomic and epigenetic instability in colorectal cancer pathogenesis. Gastroenterology. 2008;135 (4):1079-1099. doi:10.1053/j.gastro.2008.07.076

12. Elmore S. Apoptosis: a review of programmed cell death. Toxicol Pathol. 2007;35(4):495-516. doi:10.1080/01926230701320337

13. Hsiao YP, Tsai $\mathrm{CH}$, Wu PP, et al. Cantharidin induces G2/M phase arrest by inhibition of $\mathrm{Cdc} 25 \mathrm{c}$ and cyclin $\mathrm{A}$ and triggers apoptosis through reactive oxygen species and the mitochondria-dependent pathways of A375.S2 human melanoma cells. Int J Oncol. 2014;45 (6):2393-2402. doi:10.3892/ijo.2014.2689

14. Wake MS, Watson CJ. STAT3 the oncogene - still eluding therapy? FEBS J. 2015;282(14):2600-2611. doi:10.1111/febs.2015.282.issue14

15. Simon AR, Rai U, Fanburg BL, Cochran BH. Activation of the JAK-STAT pathway by reactive oxygen species. Am J Physiol. 1998;275(6):C1640-C1652. doi:10.1152/ajpcell.1998.275.6.C1640

16. Iacovelli R, Pietrantonio F, Farcomeni A, et al. Chemotherapy or targeted therapy as second-line treatment of advanced gastric cancer. a systematic review and meta-analysis of published studies. PLoS One. 2014;9(9):e108940. doi:10.1371/journal. pone. 0108940

17. Aidi Wannes W, Mhamdi B, Sriti J, et al. Antioxidant activities of the essential oils and methanol extracts from myrtle (Myrtus communis var. italica L.) leaf, stem and flower. Food Chem Toxicol. 2010;48 (5):1362-1370. doi:10.1016/j.fct.2010.03.002

18. Limsuwan S, Hesseling-Meinders A, Voravuthikunchai SP, van Dijl JM, Kayser O. Potential antibiotic and anti-infective effects of rhodomyrtone from Rhodomyrtus tomentosa (Aiton) Hassk. on Streptococcus pyogenes as revealed by proteomics. Phytomedicine. 2011;18(11):934-940. doi:10.1016/j.phymed.2011.02.007

19. Rohe A, Henze C, Erdmann F, Sippl W, Schmidt M. A fluorescence anisotropy-based Myt1 kinase binding assay. Assay Drug Dev Technol. 2014;12(2):136-144. doi:10.1089/adt.2013.534

20. Mueller PR, Coleman TR, Kumagai A, Dunphy WG. Myt1: a membrane-associated inhibitory kinase that phosphorylates Cdc2 on both threonine-14 and tyrosine-15. Science. 1995;270(5233):86-90. doi:10.1126/science. 270.5233 .86

21. Li Y, Liu Z, Guo X, Shu J, Chen Z, Li L. Aristolochic acid I-induced DNA damage and cell cycle arrest in renal tubular epithelial cells in vitro. Arch Toxicol. 2006;80(8):524-532. doi:10.1007/s00204-0060090-4

22. Yang L, Besschetnova TY, Brooks CR, Shah JV, Bonventre JV. Epithelial cell cycle arrest in G2/M mediates kidney fibrosis after injury. Nat Med. 2010;16(5):535-543, 531p following 143. doi:10.1038/nm.2144

23. Lee SW, Ahn YY, Kim YS, et al. The Immunohistochemical expression of STAT3, Bcl-xL, and MMP-2 proteins in colon adenoma and adenocarcinoma. Gut Liver. 2012;6(1):45-51. doi:10.5009/ gnl.2012.6.1.45 
24. Masuda M, Suzui M, Yasumatu R, et al. Constitutive activation of signal transducers and activators of transcription 3 correlates with cyclin D1 overexpression and may provide a novel prognostic marker in head and neck squamous cell carcinoma. Cancer Res. 2002;62 (12):3351-3355.

25. Kim DY, Cha ST, Ahn DH, et al. STAT3 expression in gastric cancer indicates a poor prognosis. J Gastroenterol Hepatol. 2009;24 (4):646-651. doi:10.1111/j.1440-1746.2008.05671.x

26. Mlejnek P, Dolezel P, Maier V, Kikalova K, Skoupa N. $\mathrm{N}$-acetylcysteine dual and antagonistic effect on cadmium cytotoxicity in human leukemia cells. Environ Toxicol Pharmacol. 2019;71:103213. doi:10.1016/j.etap.2019.103213

27. Balszuweit F, Menacher G, Schmidt A, et al. Protective effects of the thiol compounds GSH and NAC against sulfur mustard toxicity in a human keratinocyte cell line. Toxicol Lett. 2016;244:35-43. doi:10.1016/j.toxlet.2015.09.002

28. Qian M, Tan HM, Yu N, Wang T, Zhang Q. Inactivated sendai virus induces ROS-dependent apoptosis and autophagy in human prostate cancer cells. Biomed Environ Sci. 2018;31(4):280-289. doi:10.3967/ bes 2018.036

29. Cui L, Bu W, Song J, et al. Apoptosis induction by alantolactone in breast cancer MDA-MB-231 cells through reactive oxygen species-mediated mitochondrion-dependent pathway. Arch Pharm Res. 2018;41(3):299-313. doi:10.1007/s12272-017-0990-2

30. Zhu Z, Huang Y, Lv L, et al. Acute ethanol exposure-induced autophagy-mediated cardiac injury via activation of the ROS-JNKBcl-2 pathway. J Cell Physiol. 2018;233(2):924-935. doi:10.1002/ jcp. 25934
31. AlBasher G, AlKahtane AA, Alarifi S, et al. Methotrexate-induced apoptosis in human ovarian adenocarcinoma SKOV-3 cells via ROS-mediated bax/bcl-2-cyt-c release cascading. Onco Targets Ther. 2019;12:21-30. doi:10.2147/OTT.S178510

32. Seo BR, Min K-J, Woo SM, et al. Inhibition of cathepsin S induces mitochondrial ROS that sensitizes TRAIL-mediated apoptosis through p53-mediated downregulation of $\mathrm{Bcl}-2$ and c-FLIP. Antioxid redox sign. 2017;27(4):215-233

33. Li D, Ueta E, Kimura T, Yamamoto T, Osaki T. Reactive oxygen species (ROS) control the expression of Bcl-2 family proteins by regulating their phosphorylation and ubiquitination. Cancer Sci. 2004;95(8):644-650. doi:10.1111/j.1349-7006.2004.tb03323.x

34. Rasheva VI, Domingos PM. Cellular responses to endoplasmic reticulum stress and apoptosis. Apoptosis. 2009;14(8):996-1007. doi:10.1007/s10495-009-0341-y

35. Marciniak SJ, Yun CY, Oyadomari S, et al. CHOP induces death by promoting protein synthesis and oxidation in the stressed endoplasmic reticulum. Genes Dev. 2004;18(24):3066-3077. doi:10.1101/ gad. 1250704

36. Tabas I, Ron D. Integrating the mechanisms of apoptosis induced by endoplasmic reticulum stress. Nat Cell Biol. 2011;13(3):184-190. doi:10.1038/ncb0311-184

37. Sano R, Reed JC. ER stress-induced cell death mechanisms. Biochim Biophys Acta. 2013;1833(12):3460-3470. doi:10.1016/j. bbamcr.2013.06.028

38. Sun SY, Shi GJ, Sha HB, et al. IRE1 alpha is an endogenous substrate of endoplasmic-reticulum-associated degradation. Nat Cell Biol. 2015;17(12):1546-1555. doi:10.1038/ncb3266
Cancer Management and Research

\section{Publish your work in this journal}

Cancer Management and Research is an international, peer-reviewed open access journal focusing on cancer research and the optimal use of preventative and integrated treatment interventions to achieve improved outcomes, enhanced survival and quality of life for the cancer patient.
The manuscript management system is completely online and includes a very quick and fair peer-review system, which is all easy to use. Visit http://www.dovepress.com/testimonials.php to read real quotes from published authors. 